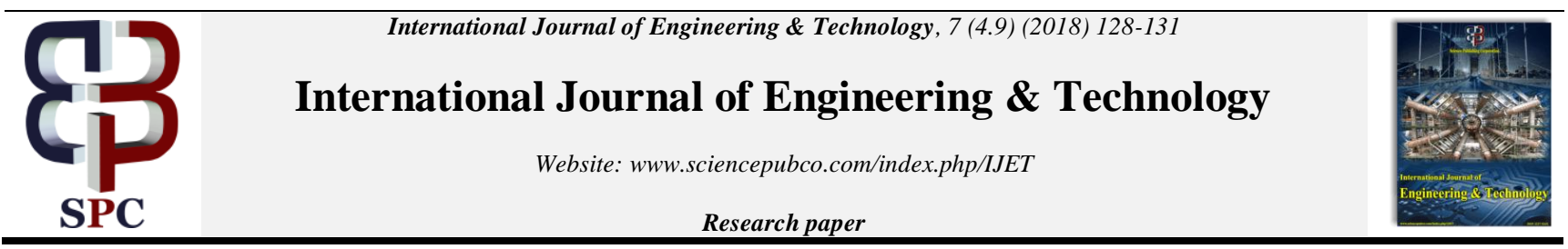

\title{
Developing Instruments to Measure Students' Logical, Critical, and Creative Thinking Competences for Bung Hatta University Students
}

\author{
Zulfa Amrina $^{* 1}$, Rita Desfitri ${ }^{2}$, Fazri Zuzano ${ }^{3}$, Yusri Wahyuni ${ }^{4}$, Hendra Hidayat ${ }^{5}$, Joni Alfino ${ }^{6}$ \\ 1,2,3,4,5 Mathematic Education, FKIP Universitas Bung Hatta Padang \\ ${ }^{6}$ English Education, FKIP Universitas Bung Hatta Padang \\ *Corresponding author E-mail: zulfa.amrina@bunghatta.ac.id
}

\begin{abstract}
This study aims to develop assessment instruments to measure students' competence to think logically, critically and creatively at Teacher Education Program of Elementary School of the Faculty of Teachers Training and Education, Bung Hatta University. The instrumentswere developed based on a self-developed questionnaire with Likert-scale (1-5 points). This research was $\mathrm{R} \& \mathrm{D}$ research using 3 stages with 3D model: defining, designing, developing and desiminating. The results of development at the expert validation stage showed some parts of the product that needed to be revised appropriately by the team of experts (design experts and materials). The products were said to be worthy by a team of experts, with an average of 9.2, then tested on a small group. Small group trial results also showed an average of 8.9 with a proper and effective classification to continue in large group trials. The large group trials also showed a valid and reliable instrument to use, with a relicompetences index of 0.86 .Furthermore, the researcher measured the competence of 42 students of Elementary School-Teacher Education based on logical,critical, and creative thinking competence. The results of the analysis showed that the percentage of categories of logical, critical, and creative thinking abilities were at the moderate / sufficient level.The research results also showed that it was necessary to improve the competences to think logically, critically, and creatively. A learning model that can improve the competence of the student is recommended accordingly.
\end{abstract}

Keywords: Thinking Skills, Competence/Competences, Problem Based Learning.

\section{Introduction}

It is necessary that higher education is able to develop science and technology and produce intellectuals, scientists, and/ or professionals who are cultured and creative, tolerant, democratic, tough character, dare to defend the truth for the sake of the nation and to improve the nation's competitiveness in facing the globalization in all fields (Act number 12 of 2012). Mathematics is onearea of sciences that studies the logic, form, arrangement, magnitude and concepts related to each other. Mathematics arise because the human thoughts are associated with ideas, processes and reasoning. Mathematics also supports the development of other sciences, such as physics, chemistry, and economics.

Because mathematics plays an important role, it becomes a compulsory subject within the Indonesia education system. However, mathematics is still considered difficult by most learners, including learners in Higher Education, particularly college student. This difficulty is caused by experience brought from basic education level.

Mathematical hierarchy makes mathematics easy to learn if the mastery of the initial concept has been mastered from elementary school level. Mastery of mathematical concepts is largely determined by the learning process undertaken in school. There are several learning components that can support the learning process are required. Two of themare strategy and teaching method in learning process that support education to run effectively and efficiently.

There aresome obstacles and difficulties within mathematics learning at universities. These result in less quality of output and outcomes of college graduates. Two of them are that learners tend to complain that the learning of mathematics is boring, theories studiedareirrelevant to the conditions that occur in the field (1). Indeed, learning mathematics can be very interesting if presented in an interesting, realistic and contextual atmosphere, for example, providing appropriate learning models.

One of the learning models that need to be developed is problem based learning(PBL). Wena (2) opines that PBL model is a learning strategy that exposes students to practical problems, i.e. students learn through problems. As such, the PBL method can develop students' logical, critical, creative thinking skills (3).

Based on the experience of the researchers, teaching mathematics in the Faculty of Teachers Training and Education, Bung Hatta University (approximately 12 years), it was found that many students hadproblems in learning mathematics. Only $10 \%$ of the students of Education for Primary School Teachers liked mathematics. For example, $60 \%$ of students who forgot the concepts that they should have mastered at the elementary or high school level. As such, material studied in high school and elementary school levels should be reviewed accordingly.

In addition to the lack of mastery of basic concepts of mathematics, $65 \%$ of students immediately panicked and even immediately gave upif given a problem, particularly a rather complex mathe- 
matics problem. If students can be more critical and creative, they will be able to solve the problem easily. This shows that the students has low competences of thinking logically, critically, and creatively. The researchers assume this condition to result in the students' low achievementof learning mathematics.

The competence of logical, critical and creative thinking abilities provides many benefits for students, both in mathematics learning and in daily life. Among them are the competences to improve and develop students' understanding on concepts anddevelop the competences to think, so that they can easily solve the problems as well as more complex issues. This is caused by a fact in which there will be many questions raised in the learning process about the various information received and the students are required to use his thinking competences to analyze and evaluate the problems using a logical reason.

The competence of logical, critical and creative thinking is an existing potential that all students have, but it takes a conducive environment to explore and realize that potential. Each individual has a different way of exploring the potential. This condition makes the competences to think logically, critically and creatively very important to affects the students' involvement actively in learning. This situation certainly brings a different impact on each student in the teaching-learning process. Basically the competences to think creatively is always concerned with the creative power of someone in creating or producing something new. In the process of learning, the competences to think logically with regard to the skills of a person in the thinking process to find various answers or solutions (4).

Students can find solutions to solve problems faced in learning mathematics by activating the competences to think logically, critically and creatively, As such, the competence to think logically, critically and creatively can also be called as a mental activity in solving the problem and providing new ideas or views on the existing problems.

The 21 st century requires Indonesian children to be able to deal with complex and structured problems. So they need the competence of creative thinking competences (creativity), critical thinking competences and problem solving, communication competences and collaboration competences (5). The competences to think logically is required in order to be able to think critically and creatively, Rohman (6) states that logical thinking is a process of reasoning about an object by connecting a series of opinions to arrive at a conclusion according to the rules of logic Poespoprodjo(7) has similar views by saying that the competences to think logically is a precise and accurate way of thinking. This logical thinking competences needs to be developed in mathematics learning because it can help students to improve their mathematical comprehension competences. Therefore, the researchers believe that efforts to improve the competences of logical thinking can bridge the improvement of students' mathematics achievement through a correct understanding of mathematical concepts.

Part of the logical thinking component is the decision. Rohman (6) states that decisions in logic are defined as human actions in and by which he acknowledges or deny a thing about another. Decision is a spiritual activity that causes the human mind to say something about something else. It can also be said that the decision is the act of the human mind that acknowledges or denies something against something else. Decisions that are the result of the actions of human reason in recognizing or denying something to something can be formulated in a sentence statement consisting of elements of the subject and predicate. The next component of logical thinking is reasoning. According to Rohman (6) reasoning is a process of a series of human activities to arrive at a conclusion (new opinion) of one or more known opinions. The known opinions or ideas are called data that are empirical information known by man.

Critical thinking is an activity through the way of thinking about ideas or ideas related to a given concept or problem described (8). In the learning process, students can do the best to achieve satisfactory learning outcomes through teacher guidance. One of which students can do is to think critically in order to solve a problem in the learning process.

Amasari (9) identified several critical thinking components, i.e. [1] basic operations of reasoning where one has the competences to explain, generalize, draw deductive conclusions, and formulate other logical steps mentally to think critically, [2] domain-specific knowledge where one must have knowledge of the topic or content in facing a problem, [3] metacognitive knowledge where effective critical thinking requires one to monitor when he/she tries to really understand an idea, realize when he/she needs new information, and how they can easily collect and learn the information, and [4] values, beliefs, and dispositions. Thinking critically means doing fair and objective judgments.

Through critical thinking competences, learners must take an active role in learning to solve every problem or to learn new knowledge. It means that the students should strive to develop a number of active thinking processes, including: [1] Listening carefully, [2] Identifying or formulate the questions, [3] organizing their thoughts, [4] paying attention to equations and differences, [5] deducing (reason from general to special, [6] distinguishing between valid and invalid conclusions logically, [7] Learning how to ask clarifying questions "(such as" in essence?", "what do you mean by this question? ", and why?"(9)

To assess the level of one's critical thinking skills, an indicator of critical thinking is required. It can be done by measuring through a test that includes five indicators: [1] recognizing assumptions, [2] inference, [3] deduction, [4] interpretation [5] evaluating arguments.

The next competence is the competences to think creatively. The competences to think creatively is a divergent thinking process, which is the competences to provide alternative answers based on the information provided (Staff IQEQ, 2008). The most important characteristics of the competences to think creatively (thinking divergent) are: [1] fluency of thinking creatively, namely, the competences to generate many ideas (ideas). The fluency of thinking emphasizes quantity, not quality, [2] Flexibility, that is the competences to propose a variety of approaches and/ or the solution of problem, [3] Elaboration, the competences to describe something in detail, [4] Originality, the competences to make a unique idea or the competences to initiate original ideas as a result of one's own thinking (10).

Some ways to develop students' creative thinking skills are: [1] Effective ways to create an active and creative learning environment are through interactive dialogue with students, not monologues, [2] Teachers should be able to ask questions that encourage creative thinking, [3] Questions which are given must be divergent, in which the students must use the process of thinking analysis, synthesis, and evaluation, [4] divergent questions require high-order thinking with the mindset from the narrow direction to the broad, [5] Respecting a question that is not [6] Respecting students' unusual and imaginative ideas, [7] Giving students the opportunity to learn on their own initiative, [8] rewarding students, [9] Spending time for students to learn and be busy without the atmosphere assessment, [10] Involving students in "brainstorming" to generate as many ideas as possible in solving problems, [11] Providing an environment that can stimulate student creativity, [12] Doing not be too controlling (authoritarian), [13] Being open to any interests and ideas arising from students. Being open does not mean always accepting but appreciating the idea, [14] Giving time and great opportunity to think and develop the idea, [15] Giving as many opportunities as possible to students to participate in making decisions, [16] Creating a warm atmosphere and [17] Creating an atmosphere of mutual respect and mutual acceptance, both between students and between teachers and students and [18] Being positive about student failures and helping them to rise from the failures.

Factors that support the development of thinking competences are as follows: [1] Situations that present incompleteness and openness, [2] Possible situations and encouraging the emergence of many questions, [3] Situations that can be encouraging in order to 
produce something, [4] Situations that emphasize self-initiative to explore, observe, question, feel, classify, record, translate, estimate, test results and communicate.

The creative thinking competences of learners in mathematics learning can be judged by the characteristics of divergent students thinking competences. The characteristics of thinking divergently or creatively proposed by Guilford in (11) are: [1] fluency, having many ideas and vocabularies to and convey something, [2] Flexibility ), the use of new ideas and ways to solve problems [3] Originality, having unique thought, ideas, and possibilities, [4] elaboration, using various details in expressing things or responses.

The competences to think creatively generally can also be reviewed based on four aspects, namely: [1] Product, emphasizing creativity from the creative work, either new or combination of old works that produce something new, [2] Person, looking at the creativity of individual that characterize the personality of the creative person, [3] The process, emphasizing how creative processes take place from the start to grow up to the realization of creative behavior, [4] Press, emphasizing the importance of factors that support the emergence of creativity in individuals (12).

\section{Methods}

This research uses $\mathrm{R} \& \mathrm{D}$ design. The development model used in this research is 3 stages with 3D model: Defining covers front end analysis, student analysis, task analysis, concept analysis, learning objective analysis, task and concept analysis. Designing includes, timetable, teamwork, and product specifications. Developing consist of [1]. Validation by the design and material experts, [2]. A small group trial involved three Lecturers of Elementary School Teacher Education, and 6 students,[3]. Large group trials to obtain validity and relicompetences of the instrument, followed by revisions and [4]. Field Trials.

\subsection{Data Collection}

The type of data used in this research was qualitative and quantitative. Qualitative data were obtained from the responses and suggestions provided by the team of experts and practitioners. Quantitative data were obtained from learner questionnaire response score, validity and relicompetences test data, and student competency measurement result. The research instrument used was in the form of validation sheet from the expert team and the questionnaire of the lecturer's response to the instrument. The data obtained through the validation sheet was qualitative data in the form of responses, suggestions, or inputs collected and presented for product improvement. Quantitative data was obtained from learner questionnaire scores and students' competence score in the form of logical thinking competences, critical thinking competences and creative thinking competences.

\subsection{Data Analysis}

The data obtained from the trial in small groups was the result of questionnaire data in the form of score. The questionnaire scores were analyzed by making the interval table (13). The interval distance is calculated by the following equation

\section{$\mathrm{S}=\frac{\text { highest score-lowest score }}{\text { interval class number }}$}

After the interval distance was obtained, it was classified as follows: very feasible, feasible, less feasible and very unfeasible. Data on large scale trials in student competence data wereto use descriptive analysis.

\section{Results and Discussion}

The results of development at the expert validation stage suggested some parts of the product that need to be revised to be appropriate by the team of experts (design experts and materials) to be tested in the field. The products were said to be worthy by a team of experts, with an average of 9.2, then tested on a small group. Small group trial results also showed an average of 8.9 with a proper and effective classification to continue in large group trials. In the large group trials also showed a valid and reliable instrument to use, with a relicompetences index of 0.86 .

Furthermore, the researcher carried out the measurement of competence of 42 students of Elementary School-Teacher Education in the form of logical, critical and creative thinking competences. The results of data analysis showed that there were not students who had the competences to think very logically, very critically, and very creatively. More data analysis results obtained were:

1. Of 42 students, only $14.29 \%$ had logical thinking competences, $66.67 \%$ had medium / logical thinking competences and $19,04 \%$ had less logical thinking competences.

2. Of the 42 students, only $19.04 \%$ had critical thinking skills, $57.147 \%$ had moderate / critical thinking skills and $23.81 \%$ had less critical thinking skills.

3. Of 42 students, $21.43 \%$ had creative thinking competences, $57,14 \%$ had medium / creative thinking competences and $21,43 \%$ had less creative thinking competences.

From the results of the analysis, it was found that the percentage of categories of logical thinking competences, critical thinking competences, and creative thinking competences at large were in moderate / sufficient category.The research results obtained also showed that it was necessary to improve the competences of logical thinking, the competences to think critically and the competences to think creatively. Efforts that can be done are using a learning model that can improve the competence of the student.

\section{Conclusion and Recommendation}

The instrument developed in this study can be used to measure students' logical, critical, and creative thinking competences. This opinion is based on the result of experts' judgement and field trial. Therefore, the researcher recommends this instrument to be applied in improving students' logical, critical, and creative thinking competences.

\section{Acknowledgments}

The researcher thanks Directorate of Higher Education for providing a grant that enable this research available. The grant is very useful for researcher.

\section{References}

[1] Fiet, J. O. 2001. The pedagogical side of entrepreneurship theory. Journal of Business Venturing, 16(2), 101-1 17.

[2] Wena. Made. 2013. Strategi Pembelajaran Inovatif Kontemporer. Jakarta timur: Bumi Aksara.

[3] Amrina, Zulfa. 2014.Peningkatan Kreatifitas Siswa Melalui Problem Based Learning, Jurnal Cerdas Proklamator ISSN 2338-0926 volume 1 nomor 1, Desember 2014, PGSD FKIP Universitas Bung Hatta.

[4] Amrina, Zulfa. 2013.Peningkatan Kemampuan Berpikir Kreatif Mahasiswa Melalui Pemberian Soal-soal Open Ended, Jurnal Cerdas Proklamator ISSN 2338-0926 volume 1 nomor 1, Juni 2013, PGSD FKIP Universitas Bung Hatta.

[5] Baswedan, Anies. "Indonesian education emergency department." Taken on 27 (2016).

[6] Rohman, Arif, Rukiyati \& Andriani, P.L. 2014. Epistemologi \& Logika Filsafat Untuk Pengembangan Pendidikan. ta :Aswaja Pressindo. 
[7] Poespoprodjo dan T. Gilarso. 2011. Logikallmu Menalar. Bandung: Pustaka Grafika.

[8] Susanto Ahmad. 2014. Teori Belajar dan Pembelajaran di Sekolah Dasar. Jakarta: Kencana.

[9] Amasari, F. H. (2011). Upaya Meningkatkan Kemampuan Berpikir Kritis dan Kreatif Siswa Kelas X Administrasi Perkantoran (AP) SMK Negeri 1 Depok pada Pembelajaran Matematika dengan Metode Problem Posing Tipe Presolution Posing. Skripsi S1 Universitas Negeri Yogyakarta.

[10] Hendrizal. 2015.Kajian Psikologi Pendidikan. Padang: Bung Hatta University Press

[11] Mudjiran, dkk. 2001. Perkembangan Peserta Didik. Padang: Direkturat Jendral Pendidikan Tinggi.

[12] Ali, Mohammad. 2006. Psikologi Remaja Perkembangan Peserta Didik. Bandung: Bumi Aksara.

[13] Widoyoko EP. Teknik penyusunan instrumen penelitian. 